\title{
DYNAMICS OF EXPORTS, INFRASTRUCTURE, AND GROWTH IN GCC: VARS AND CAUSALITY TESTING
}

\author{
Sufian Eltayeb Mohamed ${ }^{\mathrm{i}}$ \\ Sultan Qaboos University, \\ Sultanate of Oman
}

\begin{abstract}
:
The paper is concerned with analyzing the dynamic effects of exports and infrastructure on GCC ${ }^{i i}$ economic growth. Panel cointegration methodology is used to test for the existence of a long relationship between the variable. Two tests, Kao (1999) and Johansen cointegration tests are applied to check for cointegration. The results of the two tests reveal that there exists a long run co-integrating relationship between export and infrastructure proxies and economic growth in GCC countries. Additionally, fully modified least square (FMOLS) and dynamic ordinary least square (DOLS) were used to test the magnitude of the long relationship among variables. The results show that export and infrastructure variables are positive and have significant impact on the long run growth of the GCC economy. Further, fixed -effects method is selected as random effect model is rejected based on Hausman test result. The results of fixed effect show that export and infrastructure variables ate positive and statistically significant. With regard to policy, variable mixed results were obtained. As a policy recommendation the study, suggest that proper absorptive capacity such as deep financial institution, good infrastructure quality and supplementing public expenditures should be met in order to maximize the benefits of exports.
\end{abstract}

JEL: C33; O11; F10; O19; O47

Keywords: exports; infrastructure; VARs, causality, cointegration, GCC

\section{Introduction}

The export sector plays an important role in the economic growth of a country. From the perspective of international trade, exports are generators of foreign exchange, which is necessary for financing imports and other developmental projects. Infrastructure on the other hand, whether soft or hard infrastructure paly a fundamental role for accelerating the process of development and growth. Since 1990s, the GCC country invest heavily in

${ }^{i}$ Correspondence: email sufian@squ.edu.om

ii GCC includes, Saudi Arabia, U.A.E, Qatar, Oman, Kuwait and Bahrain 
the infrastructure sector because they believe that this sector will boost their economic growth and help them to be competitive in the international markets. This believe is supported by many empirical studies that demonstrates the positive impact of infrastructure on economic growth and unveil that transport plays a vital role in economic activity either directly or as a complement to other factors of production.

The main objectives of this paper are to study the effect of export and infrastructure on economic growth of a panel of six gulf countries during the period 19902019 and to produce new evidence on the economic growth and these variables. Therefore, a test of the relationship between economic growth and export, infrastructure for these countries could reveal important information on this issue. Secondly, very few studies were conducted to test the impact of export and infrastructure on economic growth of GGC. Overall, this paper examines the dynamic relationship between export, infrastructure on economic growth of GGC.

The paper is organized into five sections. A brief literature review is discussed section 2. Section 3 describes the model specification and data Section 4 presents the analysis and discussion. Section 5 concludes the paper and provides some recommendations based on the empirical findings

\section{Literature Review}

In this section we shall shed some light on previous studies that dealt with exports and infrastructure and how they affect the economic growth of a country. As for exports, massive literature shows that there are numerous studies that explore the evidence of the positive impact of export expansion on economic growth (Heitger, 1987; Lussier, 1993; Gylfason, 1999; Ramos, 2001). More recently, Hagemejer and Muck (2019) in their study of export-led growth and its determinants in CEEC countries, they reveal that exports have played a major role in determining GDP growth of these countries. Moreover, Taghavi, et.al (2012) investigated VAR method between import, export and economic growth in Iran during the period 1962- 2011. The findings show a long run relationship between the variables considered. Based on the results, export had direct and positive impact on economic growth in the long run. Also import had a significant and negative impact on economic growth, then import had a negative relationship with economic growth in the long term.

On the other hand, the impact of infrastructure on economic growth has been extensively studied over the years. The basic theoretical framework of the impact of public capital on economic growth was developed first by Arrow and Kurz (1970). Subsequently, many empirical studies were conducted to test the relationship between infrastructure and economic growth. Calderon and Serven (2008) analyze the impact of infrastructure on economic performance of African countries. Using panel data for a large sample of countries for the period 1960-2005, they employ growth regressions estimated through a Generalized Method of Moments estimator and evaluate the impact of several types of infrastructure assets, as well as measures of quality of their services. Their findings suggest that both infrastructure stock and quality are positively and significantly 
related to real GDP per capita growth. In their study of "Trade Can Be Good for Growth: The Role of Policy Complementarities" Chang, Kaltani, and Loayza (2009), show that, the quality of infrastructure (proxies by the number of main telephone lines per capita in their paper) is an important determinant of the impact of trade reforms on economic growth. Yet the number of telephone lines is only a partial indicator of infrastructure. Other literature has been examining how many other dimensions of hard infrastructure (e.g., telephone lines and other information and communications technology infrastructure, ports, and roads) and soft infrastructure (e.g., border and transport efficiency, and the business and regulatory environment) affect international trade flows. Most of this literature has used the empirical workhorse of studies in international trade-the gravity equation ${ }^{\text {iii. }}$.

However, the complementary role between infrastructure and export to boost economic growth has been ignored in previous literature. Only few studies have indirectly referred to it. Some studies have concluded that infrastructure development has a positive effect on trade through lower transport costs. Using a panel of bilateral trade-flow data for 1988-2002, Francois and Manchin (2013) concluded that transport infrastructure not only increases trade volumes, but also increases the probability of trade occurring. Lederman, Maloney, and Servén (2005) have found that the efficient provision of infrastructure is crucial for the success of trade-liberalization strategies aimed at optimal resource allocation and export growth. Conversely, some studies suggested that growth in international trade stimulates public infrastructure development. Since trade is a demand determinant for transport and logistics, growth in international trade will affect their growth (Lee and Rodrigues 2006).

\section{Model Specification and Data}

Following the empirical literature, we construct a model to test the relationship between exports, infrastructure, and economic growth in the GCC over the period, 1990-2019,

GDPGRit $=f(E X P T t$, FXTELt, ELECTt, INFt, GFCEXt, DCBt $)$,

Alternatively, the Regression model will look as fellow:

$\mathrm{GPGDP}_{\mathrm{it}}=\beta_{0 \mathrm{i}}+\beta_{1} E X P T t+\beta_{2}$ FXTELt $+\beta_{3} E L E C T t+\beta_{4}\left(E X P T t^{*} F X T E L t+\beta_{5} E X P T t^{*} E L E C T t\right.$ $+\beta_{6} E_{X P T^{*}} D C B t+\beta_{7} D C B t+G F C E X t+I N F t+\varepsilon_{\text {it }}$

Where real Real GDP at constant 2011 national prices (in mil. 2011US\$) denoted as GDPGRit, is a dependent variable. EXPTt, is a measure real exports of goods and services (BoP, current US\$), FXTELt, is fixed telephone subscriptions (total) is used as a proxy for infrastructure, ELECTt is electric power consumption (kWh per capita) is also used as a

\footnotetext{
iii Olarreaga, M. 2016. Trade, Infrastructure, and Development. ADBI Working Paper 626. Tokyo: Asian Development Bank Institute. Available: https://www.adb.org/publications/tradeinfrastructure-and$\underline{\text { development }}$
} 
proxy for infrastructure. GFCEXt is General government final consumption expenditure (\% of GDP), INFt is a measure of inflation rate and DCBt is domestic credit to private sector by banks (\% of GDP). The study used annual data over the period of 1990-2019. The world Development Indicators prepared by World Bank are the source of data to this study. All variables have been transformed into natural logarithms (ln) to help mobilize stationarity.

Table 1: Variables Codes and Expected Signs

\begin{tabular}{|c|c|c|c|c|}
\hline Variable & Definition & $\begin{array}{l}\text { Codes of } \\
\text { Variable }\end{array}$ & $\begin{array}{l}\text { Expected } \\
\text { sign }\end{array}$ & Source \\
\hline $\begin{array}{l}\text { Dependent } \\
\text { Variable }\end{array}$ & $\begin{array}{l}\text { Real GDP at constant } 2011 \text { national } \\
\text { prices (in mil. 2011US\$) }\end{array}$ & GDPGR & & $\begin{array}{c}\text { Penn Table } \\
9.1^{*}\end{array}$ \\
\hline \multirow{2}{*}{$\begin{array}{l}\text { Independent } \\
\text { Variable }\end{array}$} & $\begin{array}{l}\text { Real Exports of Goods and Services } \\
\text { (BoP, current US\$) }\end{array}$ & EXPT & + & WDI, 2018 \\
\hline & $\begin{array}{l}\text { Fixed Telephone Subscriptions (total) } \\
\text { Electric power consumption (kWh per } \\
\text { capita }\end{array}$ & $\begin{array}{l}\text { FXTEL } \\
\text { ELECT }\end{array}$ & + & $\begin{array}{l}\text { WDI, } 2018 \\
\text { WDI, } 2018\end{array}$ \\
\hline \multirow{3}{*}{$\begin{array}{l}\text { Control } \\
\text { Variables }\end{array}$} & Inflation, GDP deflator (annual \%) & INF & - & WDI, 2018 \\
\hline & $\begin{array}{l}\text { General government final consumption } \\
\text { expenditure (\% of GDP) }\end{array}$ & GFCEX & - & WDI, 2018 \\
\hline & $\begin{array}{l}\text { Domestic credit to private sector by } \\
\text { banks (\% of GDP). }\end{array}$ & $\mathrm{DCB}$ & + & WDI, 2018 \\
\hline
\end{tabular}

*Source: The data are extracted from Penn World Table, version 9.1. Description is at the reference: Feenstra, Robert C., Robert Inklaar and Marcel P. Timmer (2015), "The Next Generation of the Penn World Table" American Economic Review, 105(10), 3150-3182, available for download at www.ggdc.net/pwt.

\section{Empirical Results}

\subsection{Descriptive Analysis}

The descriptive statistics, minimum, maximum, mean, and standard deviation (Std. Dev.) of these variables is recorded below in Table 2. Over the period 1990-2019, EXPT-DCB has a maximum value (1134.925) and high standard deviation (225.0717)

Table 2: Summary Statistics for the Model Variables

\begin{tabular}{|l|c|c|c|c|c|}
\hline Variable & Mean & Median & Maximum & Minimum & Std. Dev. \\
\hline LNGDPGR & 4.478031 & 4.350563 & 4.843102 & 4.173278 & 0.218917 \\
\hline LNEXPT & 10.56865 & 10.59197 & 11.60354 & 9.269727 & 0.570124 \\
\hline LNELECT & 3.990834 & 4.07439 & 4.365718 & 3.188695 & 0.279987 \\
\hline LN_FXTEL & 5.731876 & 5.640981 & 6.73138 & 4.973105 & 0.459878 \\
\hline INF & 4.83201 & 3.246227 & 144.6836 & -25.95839 & 15.09032 \\
\hline GFCEX & 19.48676 & 19.3895 & 76.22213 & 3.513854 & 8.538737 \\
\hline EXPT_FXTEL & 60.79314 & 59.15848 & 77.56952 & 47.7228 & 7.847697 \\
\hline EXPT_ELET & 42.20078 & 42.80935 & 47.49944 & 31.94134 & 3.887832 \\
\hline EXPT_DCB & 493.5224 & 432.1106 & 1134.925 & 135.7661 & 225.0717 \\
\hline DCB & 46.33048 & 41.57453 & 105.1868 & 14.16827 & 20.14864 \\
\hline
\end{tabular}


Table 3 shows the correlation matrix. The correlation indicates a positive correlation between the LNEXPT, and LNELECT with. LNGDPGR.

Table 3: Correlation matrix

\begin{tabular}{|c|c|c|c|c|c|c|c|c|c|c|}
\hline Variable & LNGDPGR & LNEXPT & LNELECT & LN_FXTEL & INF & GFCEX & EXPT_FXTEL & EXPT_ELET & EXPT_DCB & DCB \\
\hline LNGDPGR & 1 & & & & & & & & & \\
\hline LNEXPT & 0.237422 & 1 & & & & & & & & \\
\hline LNELECT & 0.434286 & 0.145334 & 1 & & & & & & & \\
\hline LN_FXTEL & -0.00049 & 0.824926 & -0.11687 & 1 & & & & & & \\
\hline INF & 0.071363 & -0.00786 & 0.053772 & -0.07962 & 1 & & & & & \\
\hline$\overline{\text { GFCEX }}$ & -0.38675 & -0.36423 & -0.44982 & -0.04333 & -0.11181 & 1 & & & & \\
\hline EXPT_FXTEL & 0.084681 & 0.930991 & -0.01674 & 0.973579 & -0.05202 & -0.17484 & 1 & & & \\
\hline EXPT_ELET & 0.468428 & 0.69002 & 0.815607 & 0.387825 & 0.033094 & -0.54463 & 0.525931 & 1 & & \\
\hline EXPT_DCB & 0.159236 & 0.435213 & 0.552574 & 0.126892 & -0.17054 & -0.27823 & 0.256673 & 0.66965 & 1 & \\
\hline $\mathrm{DCB}$ & 0.133546 & 0.339137 & 0.574355 & 0.038548 & -0.17778 & -0.25537 & 0.160911 & 0.629277 & 0.993614 & 1 \\
\hline
\end{tabular}

\subsection{Panel Unit Root Test}

To determine the order of integration, the study uses four sets of unit root tests; as reported in Table 3. The results which reported in Table 4 show that all the variables except INF are non-stationary at levels. After taking the first difference the variables to perform stationarity all the variables were confirmed to be stationary. Therefore, the study moves to check for co-integration by using two different tests as we shall see later.

Table 4: Panel unit root test

\begin{tabular}{|l|c|c|c|c|c|c|c|c|}
\hline \multirow{2}{*}{ Variables } & \multicolumn{2}{|c|}{$\begin{array}{c}\text { Levin, Lin } \\
\text { \& Chu t }\end{array}$} & \multicolumn{2}{c|}{$\begin{array}{c}\text { Im, Pesaran and } \\
\text { Shin W-stat }\end{array}$} & \multicolumn{2}{c|}{$\begin{array}{c}\text { ADF - Fisher } \\
\text { Chi-square }\end{array}$} & \multicolumn{2}{c|}{$\begin{array}{c}\text { PP - Fisher } \\
\text { Chi-square }\end{array}$} \\
\cline { 2 - 10 } & $\begin{array}{c}\text { Level } \\
p \text {-value }\end{array}$ & $\begin{array}{c}\text { First } \\
\text { Difference } \\
p \text {-value }\end{array}$ & $\begin{array}{c}\text { Level } \\
p \text {-value }\end{array}$ & $\begin{array}{c}\text { First } \\
\text { Difference } \\
p \text {-value }\end{array}$ & $\begin{array}{c}\text { Level } \\
p \text {-value }\end{array}$ & $\begin{array}{c}\text { First } \\
\text { Difference } \\
p \text {-value }\end{array}$ & $\begin{array}{c}\text { Level } \\
p \text {-value }\end{array}$ & $\begin{array}{c}\text { First } \\
\text { Difference } \\
p \text {-value }\end{array}$ \\
\hline LNGDPGR & 0.2768 & 0.0056 & 0.1140 & 0.0002 & 0.1559 & 0.0000 & 0.0235 & 0.0000 \\
\hline LNEXPT & 0.0664 & 0.0000 & 0.8040 & 0.0000 & 0.7071 & 0.0000 & 0.9990 & 0.0000 \\
\hline LNELECT & 0.3372 & 0.0000 & 0.0823 & 0.0000 & 0.0022 & 0.0000 & 0.8457 & 0.0000 \\
\hline LN_FXTEL & 0.4010 & 0.0021 & 0.3503 & 0.0000 & 0.1241 & 0.0000 & 0.0890 & 0.0000 \\
\hline INF & 0.0456 & 0.0000 & 0.0000 & 0.0000 & 0.0000 & 0.0000 & 0.0000 & 0.0000 \\
\hline DCB & 0.3458 & 0.0000 & 0.9020 & 0.0000 & 0.9047 & 0.0000 & 0.9990 & 0.0000 \\
\hline EXPT_FXTEL & 0.2234 & 0.0000 & 0.8314 & 0.0000 & 0.5126 & 0.0000 & 0.9933 & 0.0000 \\
\hline EXPT_ELET & 0.1143 & 0.0000 & 0.6170 & 0.0000 & 0.3838 & 0.0000 & 0.9988 & 0.0000 \\
\hline EXPT_DCB & 0.5191 & 0.0000 & 0.9693 & 0.0000 & 0.9649 & 0.0000 & 0.9997 & 0.0000 \\
\hline
\end{tabular}

Lag order selection criterion is provided in Table 5. With the exception of SC that called for two lags, all the other criteria including AIC, HQ, final prediction error (FPE) and Sequential likelihood ratio (LR) called for three lags. Hence, lag three is considered as optimum lag in our model. 
Table 5: VAR Lag Order Selection Criteria

\begin{tabular}{lcccccc}
\hline \hline Lag & \multicolumn{7}{c}{ LogL } & LR & FPE & AIC & SC & HQ \\
\hline \hline & & & & & \\
0 & & & & & & \\
1 & -719.0785 & NA & $2.29 \mathrm{e}-05$ & 12.01783 & 12.20267 & 12.09290 \\
2 & 855.2277 & 2914.418 & $3.30 \mathrm{e}-16$ & -12.94591 & $-11.28230^{*}$ & -12.27026 \\
3 & 902.5206 & 81.29679 & $4.41 \mathrm{e}-16^{*}$ & $-12.66976^{*}$ & -9.527385 & $-11.39352^{*}$ \\
4 & 941.4197 & 61.72419 & $6.90 \mathrm{e}-16$ & -12.25487 & -7.633729 & -10.37805 \\
5 & 982.6855 & 60.02297 & $1.07 \mathrm{e}-15$ & -11.87910 & -5.779192 & -9.401694 \\
6 & 1038.109 & 73.28788 & $1.38 \mathrm{e}-15$ & -11.73735 & -4.158674 & -8.659358 \\
7 & 1107.460 & 82.53330 & $1.50 \mathrm{e}-15$ & -11.82579 & -2.768353 & -8.147220 \\
8 & 1175.347 & 71.81426 & $1.81 \mathrm{e}-15$ & -11.89004 & -1.353835 & -7.610884 \\
& 1267.020 & $84.85449^{*}$ & $1.64 \mathrm{e}-15$ & -12.34744 & -0.332477 & -7.467708 \\
\hline \hline
\end{tabular}

* indicates lag order selected by the criterion

LR: sequential modified LR test statistic (each test at $5 \%$ level)

FPE: Final prediction error

AIC: Akaike information criterion

SC: Schwarz information criterion

HQ: Hannan-Quinn information criterion

\subsection{Panel Cointegration Test}

After determining the order of integration, the next step is to check the possibility of longrun relationship between variables. So, Kao (1999), and Johansen cointegration tests are applied to check for cointegration. The null hypothesis for the two tests is that there is no cointegration in the series, and the alternative hypothesis is that there is cointegration in the series. The results of the panel cointegration tests are presented in Table 6, and 7.

The result of Kao (1999) as presented in Table 6 showed that the p-values is less than $5 \%$ therefore we can reject the null hypothesis of no cointegration, and accept the alternative hypothesis of cointegration.

Table 6: Results of Kao's Residual Cointegration Test

\begin{tabular}{lcc}
\hline \hline & & \\
ADF & t-Statistic & Prob. \\
\cline { 2 - 3 } & & -3.152302 \\
\hline \hline \\
Residual variance & & 0.0008 \\
HAC variance & 0.000297 \\
\hline \hline
\end{tabular}

Table 7 below show the results of Johansen cointegration test. The trace test indicates seven cointegrating equations while max-eigen test have nine cointegrating equations at the 0.05 level. 
Table 7: Johansen Cointegration Test

Hypothesized

No. of CE(s)
Fisher Stat.*

(from trace test)
Fisher Stat.*

Prob. (from max-eigen test) Prob.

\begin{tabular}{lllll} 
None & 6.931 & 0.7319 & 6.931 & 0.7319 \\
At most 1 & 4.159 & 0.9399 & 41.00 & 0.0000 \\
At most 2 & 1.386 & 0.9992 & 75.07 & 0.0000 \\
At most 3 & 75.07 & 0.0000 & 75.07 & 0.0000 \\
At most 4 & 231.1 & 0.0000 & 118.4 & 0.0000 \\
At most 5 & 169.7 & 0.0000 & 112.5 & 0.0000 \\
At most 6 & 126.0 & 0.0000 & 72.84 & 0.0000 \\
At most 7 & 76.72 & 0.0000 & 59.24 & 0.0000 \\
At most 8 & 30.99 & 0.0006 & 26.77 & 0.0028 \\
At most 9 & 18.43 & 0.0482 & 18.43 & 0.0482 \\
\hline
\end{tabular}

To conclude the results of the tests of Johansen's test and Kao's test agree. Thus, it can be concluded that the all variables have robust long-run association in GCC countries.

\subsection{FMOLS and DOLS results}

Based on the results of cointegration obtained from the two tests above and the confirmation of the long-run association between variables we can proceed further to estimate the magnitude of the long run relationship between the variables by applying panel Fully Modified Ordinary Least Squares (FMOLS) and panel Dynamic Ordinary Least Squares (DOLS) estimators. Table 8 and 9.

Table 8: Results Panel Fully Modified Least Squares (FMOLS)

\section{Dependent Variable: LNGDPGR}

\begin{tabular}{lcccc}
\hline \hline & & & & \\
Variable & Coefficient & Std. Error & t-Statistic & Prob. \\
& & & & \\
& & & & \\
LNEXPT & 0.629261 & 0.246296 & 2.554901 & 0.0117 \\
LNELECT & 2.179696 & 0.562227 & 3.876898 & 0.0002 \\
LN_FXTEL & 0.041938 & 0.323750 & 0.129537 & 0.8971 \\
INF & -0.000355 & 0.000329 & -1.078187 & 0.2828 \\
GFCEX & 0.002275 & 0.001259 & 1.806260 & 0.0730 \\
EXPT_FXTEL & -0.014524 & 0.027159 & -0.534794 & 0.5936 \\
EXPT_ELET & 0.231671 & 0.056861 & 4.074301 & 0.0001 \\
EXPT_DCB & -0.003838 & 0.000889 & -4.317059 & 0.0000 \\
DCB & 0.038734 & 0.009592 & 4.038269 & 0.0001 \\
& & & & \\
\hline \hline
\end{tabular}


DYNAMICS OF EXPORTS, INFRASTRUCTURE, AND GROWTH IN GCC: VARS AND CAUSALITY TESTING

\begin{tabular}{llll}
\hline S.E. of regression & 0.038819 & Sum squared resid & 0.213986 \\
Durbin-Watson stat & 0.503224 & Long-run variance & 0.002936 \\
& & \\
\hline \hline
\end{tabular}

Table 9: Results of Panel Dynamic Least Squares (DOLS) Dependent Variable: LNGDPGR

\begin{tabular}{lcccc}
\hline \hline Variable & Coefficient & Std. Error & t-Statistic & Prob. \\
& & & \\
& & & \\
& & & \\
LNEXPT & 0.174225 & 0.052519 & 3.317396 & 0.0011 \\
LNELECT & -4.547002 & 0.649978 & -6.995627 & 0.0000 \\
LN_FXTEL & 4.027202 & 0.500580 & 8.045071 & 0.0000 \\
INF & 0.001174 & 0.000854 & 1.374922 & 0.1711 \\
GFCEX & -0.004188 & 0.001905 & -2.198844 & 0.0294 \\
EXPT_FXTEL & -0.366255 & 0.043413 & -8.436551 & 0.0000 \\
EXPT_ELET & 0.474903 & 0.064718 & 7.337987 & 0.0000 \\
& & & & \\
\hline \hline
\end{tabular}

The results of both FMOLS and DOLS are reported in Table 8 and 9. The results of FMOS method show that LNEXPT and LNELECT have positive and long run significant effect on growth of GCC countries. With regard to policy, variable mixed results were obtained. Gross capital formation as percent of GDP is found to have negative and significant impact on the long run growth of the economy in DOLS model but positive and insignificant in FMOLS. Inflations as an indicator for economic stability is found to have positive and insignificant impact on the long run growth of the economy.

\subsection{Fixed Effect VS Random Effects Model}

In the following section we employ the panel fixed effect or random effect model. The choice of the method is based on the result of Hausman test where the null hypothesis is that the random effect model is more appropriate vs. the alternative hypothesis the fixed effect model is more appropriate.

After conducing Hausman test the result of test show that the p-value $<0.05$ then Ho is rejected, as a result we select the fixed effect model (FEM).

Table 10: Hausman Test Result

Test Summary $\quad$ Chi-Sq. Statistic $\quad$ Chi-Sq. d.f. $\quad$ Prob.


Since the results of Hausman test came in favor of fixed effect model, we run regression for panel fixed effect and the results are given in Table 11. The results show significant and positive effect of LNEXPT and LNELECT variables on economic growth of GCC countries. For policy variables, inflation and GFCEX are both insignificant.

Table 11: Fixed Effect Results

Dependent Variable: LNGDPGR

\begin{tabular}{lcccc}
\hline \hline & & & & \\
Variable & Coefficient & Std. Error & t-Statistic & Prob. \\
\hline \hline & & & & \\
LNEXPT & & & & \\
LNELECT & 0.403488 & 0.158743 & 2.541760 & 0.0121 \\
LN_FXTEL & 1.764805 & 0.365697 & 4.825871 & 0.0000 \\
INF & 0.272031 & 0.210304 & 1.293513 & 0.1978 \\
GFCEX & -0.000248 & 0.000218 & -1.139424 & 0.2564 \\
EXPT_FXTEL & 0.001098 & 0.000808 & 1.359364 & 0.1761 \\
EXPT_ELET & -0.032320 & 0.017819 & -1.813835 & 0.0717 \\
EXPT_DCB & 0.186306 & 0.036982 & 5.037758 & 0.0000 \\
DCB & -0.003127 & 0.000586 & -5.336724 & 0.0000 \\
C & 0.031690 & 0.006317 & 5.016440 & 0.0000 \\
& 8.383469 & 1.664392 & 5.036957 & 0.0000 \\
\hline \hline
\end{tabular}

R-squared

Adjusted R-squared

S.E. of regression

Sum squared resid

Log likelihood

F-statistic

Prob(F-statistic)

0.972436
0.969828
0.038026
0.214004
309.5070
372.9469
0.000000

Mean dependent var

4.478031

0.218917

$-3.613582$

Akaike info criterion

$-3.328882$

Schwarz criterion

$-3.497997$

Hannan-Quinn criter.

0.385024

\subsection{Results of Granger-Causality Tests}

Table 12 reveals the causality effect of the variables of interests adopted in this paper. The analysis shows that there is unidirectional causality running from the interaction term of export to real growth rate.

Table 12: Granger Causality Tests

\begin{tabular}{lccc}
\hline Variables & F-Stat. & p-value & Causality \\
\hline LNEXPT $\rightarrow$ LNGDPGR & 0.79220 & 0.4548 & No \\
\hline EXPT_FXTEL $\rightarrow$ LNGDPGR & 2.70503 & 0.0702 & Yes \\
\hline EXPT_ELET $\rightarrow$ LNGDPGR & 4.403 & 0.043 & Yes \\
\hline LNELECT $\rightarrow$ LNGDPGR & 0.867 & 0.358 & No \\
\hline DCB $\rightarrow$ LNGDPGR & 3.52613 & 0.0234 & Yes \\
\hline EXPT_DCB $\rightarrow$ LNGDPGR & 3.90131 & 0.0222 & Yes \\
\hline
\end{tabular}




\section{Conclusion and Policy Implications}

The paper is concerned with the growth impact of Export and infrastructure in GCC countries. By employing a panel data methodology for the period of 1990-2019 the study investigates whether the export and infrastructure have a positive effect on GCC countries. For initial check of the series, the study employs four panel unit root test and the results show that all series are integrated of order one after the first difference.

Panel cointegration methodology is used to test for the existence of a long relationship between the variable. Two tests, Kao (1999) and Johansen cointegration tests are applied to check for cointegration. The results of the two tests reveal that there exists a long run co-integrating relationship between export and infrastructure proxies and economic growth in GCC countries. To test the magnitude of the long relationship among variables fully modified least square (FMOLS) and dynamic ordinary least square (DOLS) were used. The results show that export and infrastructure variables are positive and have significant impact on the long run growth of the economy.

Further, fixed -effects method is selected as random effect model is rejected based on Hausman test result. The results of fixed effect show that export and infrastructure variables ate positive and statistically significant. With regard to policy, variable mixed results were obtained.

As a policy recommendation the study, suggest that proper absorptive capacity such as deep financial institution, good infrastructure quality and supplementing public expenditures should be met in order to maximize the benefits of exports.

\section{Conflict of Interest Statement}

The author declares no conflicts of interests.

\section{About the Author}

Sufian Eltayeb Mohamed Abdel-Gadir is Assistant Professor working at Sultan Qaboos University, Faculty of Law. His teaching and research experience extend to more than 20 years. He has published many papers in various peer reviewed and Scopus indexed journals and presented many papers in international conferences. His main interest focuses on FDI, Climate Change, Quality in higher education, and econometric modelling.

\section{References}

Arrow, Kenneth, J. and Mordekai Kurz (1970). "Public Investment, The Rate of Return and Optimal Fiscal Policy." Johns Hopkins.

Beningo, S. U.S.-China Trade Growth and America's Transportation System. Bureau of Transportation Statistics Special Report, SR-007, U.S. Department of Transportation, 2008 
Borrone, L. C. "Sparking the Globalized Trade and Transportation Connection: Supplying Freight System Responses to Global Trade Demands." Transportation Research Record No.1906, (2005): 5-16.

Calderon and Serven (2008). "Infrastructure and Economic Development in Sub-Saharan Africa." World Bank Policy Research Working Paper No. 4712. The World Bank.

Chang, R., L. Kaltani, and N. Loayza (2009). Trade Can Be Good for Growth: The Role of Policy Complementarities. Journal of Development Economics 90(1): 33-49

Francois, J. F. and M. Manchin. "Institutions, Infrastructure, and Trade." World Development 46, (2013): 165-175.

Giles, J. A., and Williams, C. L. (2000b). "Export-led growth: A survey of the empirical literature and some non-causality results. Part 2" Journal of International Trade and Economic Development 9(4): 445-470.

Gylfason, T. (1999). “Exports, Inflation and Growth.” World Development 27(6): 10311057.

Hagemejer, J., \& Muck, J. (2019). Export-led growth and its determinants Evidence from CEEC countries. The World Economy, 42(7), 1994. Retrieved from https://doi.org/10.1111/twec.12790

Hatemi-J, A. (2002). "Export Performance and Economic Growth Nexus in Japan: A Bootstrap Approach." Japan and the World Economy 14 (1): 25-33.

Heitger, B. (1987). Import protection and export performance: Their impact on economic growth. Weltwirtschaftliches Archiv, 123(2), 249-261. doi:10.1007/BF02706662

Lederman, D., W. Maloney, and L. Servén (2005). Lessons from NAFTA for Latin America and the Caribbean. Palo Alto and Washington, DC: Stanford University Press and World Bank

Lee, J. Y. and J. P. Rodrigue. "Trade Reorientation and Its Effects on Regional Port Systems: The Korea China Link along the Yellow Sea Rim." Growth and Change 37 (4), (2006): 597-619

Leichenko, R. M. "Exports, Employment, and Production: A Causal Assessment of US States and Regions." Economic Geography 76 (4), (2000): 303-325.

Limao, N. and A. J. Venables. "Infrastructure, Geographical Disadvantage, Transport Costs, and Trade." The World Bank Economic Review 15 (3), (2001): 451-479

Lussier, M. (1993). Impacts of exports on economic performance: A comparative study. Journal of African Economics, 2(1), 106-127

Marin, D. "Is the Export-Led Growth Hypothesis Valid for Industrialized Countries?" Review of Economics and Statistics 74 (4), (1992): 678-688

Nordas, H. K. and R. Piermartini. Infrastructure and Trade. Working paper, No. ERSD2004-04, World Trade Organization, Switzerland, 2004.

Ramos, F. R. (2001). “Exports, imports, and economic growth in Portugal: Evidence from causality and cointegration analysis." Economic Modelling 18(4): 613-623.

Taghavi, M., Goudarzi, M., Masoudi, E., Gashti, H., P. (2012). Study on the Impact of Export and Import on Economic Growth in Iran, Journal of Basic and Applied Scientific Research, 2(12): 12787-12794. 
Zestos, G. K. and X. Tao. "Trade and GDP Growth: Causal Relations in the United States and Canada." Southern Economic Journal 68 (4), (2002): 859-874. applied to their work. Under the terms of this license, no permission is required from the author(s) or publisher for members of the community to copy, distribute, transmit or adapt the article content, providing a proper, prominent and unambiguous attribution to the authors in a manner that makes clear that the materials are being reused under permission of a Creative Commons License. Views, opinions and conclusions expressed in this research article are views, opinions and conclusions of the author(s). Open Access Publishing Group and European Journal of Economic and Financial Research shall not be responsible or answerable for any loss, damage or liability caused in relation to/arising out of conflict of interests, copyright violations and inappropriate or inaccurate use of any kind content related or integrated on the research work. All the published works are meeting the Open Access Publishing requirements and can be freely accessed, shared, modified, distributed and used in educational, commercial and non-commercial purposes under a Creative Commons Attribution 4.0 International License (CC BY 4.0). 